\title{
A Welfare Model of Street Vendors: Cases from Denpasar, Bali, Indonesia
}

\author{
Desak Putu Eka Nilakusmawati (Corresponding author) \\ Mathematics Department, Udayana University \\ Kampus Bukit Jimbaran, Badung, Bali, Indonesia \\ E-mail: nilakusmawati@unud.ac.id
}

\author{
Made Susilawati \\ Mathematics Department, Udayana University \\ Kampus Bukit Jimbaran, Badung, Bali, Indonesia \\ E-mail: mdsusilawati@unud.ac.id
}

\section{Geoffrey Wall}

Department of Geography and Environmental Management, University of Waterloo

Waterloo, Ontario N2L 3G1, Canada

E-mail: gwall@uwaterloo.ca

Received: May 9, 2019 Accepted: May 30, 2019 Online published: June 24, 2019

doi:10.5296/ijhrs.v9i3.14973 URL: https://doi.org/10.5296/ijhrs.v9i3.14973

\begin{abstract}
This study determines the socio-economic characteristics of street vendors in Denpasar, Bali, Indonesia and proposes a welfare model to examine their well-being. The results showed that street vendors in Denpasar are mostly male, married, with an average age of 39. Most are recent migrants who rent their housing. The majority sell food and beverages from carts and work almost 8 hours per day. Most are self-employed and may be assisted by family labor. Most do not do bookkeeping for their business activities and many are not registered businesses. Most have little access to capital and do not participate in empowerment programs in the form of education/training in business skills. Binary logistic regression analysis shows that the incomes of street vendors are related positively to marital status, age,
\end{abstract}


employment status, physical facilities, and presence of bookkeeping.

Keywords: Informal sector, welfare model, empowerment, street vendors

\section{Introduction}

In Indonesia, almost two-thirds of workers operate in the informal sector (ILO, 2002). Neither the government nor private sector has been able to provide sufficient jobs in the formal sector so that the informal sector provides employment for many residents. However, the nature and conditions of employment in the informal sector often result in marginal businesses with many challenges (Soewartoyo, 2010). The relevant economic activities often have irregular activity patterns, are untouched by government rules and regulations, rely on limited and scarce capital and result in small incomes.

Street vendors are prominent examples of informal sector workers. They are commonly self-employed, work alone or with family members who may be unpaid, and have no fixed place of work (Leibo, 2004). National Labor Force Survey data show that half (49.9 percent) of the workforce in the urban areas of Bali are in the informal sector (BPS, 1996). The proportion is lower in rural areas and, when rural and urban areas are combined, the figure was 41.1 percent. In Indonesia as a whole the figure reached 64.7 percent (BPS, 2002). According to data from BPS Province Bali (2012), in August 2012 as many as 1.204 million people (53.05 percent) worked in informal activities and 1.065 million people (46.95 percent) worked in formal activities. Thus, in both Indonesia and Bali, informal employment is not unusual but is the norm and informal employment is more common than formal.

The informal sector is extremely important in the absorption of the labor force and in supporting overall economy. Since formal requirements are avoided, it is a shelter for workers who do not possess or are unable to obtain them. The modern formal sectors have been unable to absorb labor that is surplus to agriculture, causing workers to turn to the informal sector. The formal sector benefits greatly from the existence of the informal sector, and there are even indications that the informal sector may subsidize the formal sector. Long and Wall (1995) noted that small-scale, informal-sector employment offers opportunities for indigenous, grassroots participation in the tourism industry, which is the major economic sector in Bali.

According to legal status, formal and informal activities differ in many ways. Formal sector characteristics include difficult entry, frequent reliance on imported resources, corporate ownership, large scale of operation, capital-intensiveness, and often imported technology, formally-acquired skills, and protected markets through tariffs, quotas, and licences (ILO, 1972). In contrast, informal activities generally exhibit ease of entry, reliance on indigenous resources, family ownership, small scale operation, labor intensiveness, skills acquired outside the formal school system, part-time labor, locally-based ventures, and unregulated and competitive markets (ILO, 1985).

Friedmann and Sullivan (1974) differentiated informal sector into two groups: small enterprise groups and self-employed workers or casual workers. While the formal sector divided into three major groups: 1) formal sector workers; 2) supervisors, 
foremen and administrative workers; 3 ) high employee groups, professionals, managers, large and medium entrepreneurs (Effendi, 1993).

Hidayat (1978) described the characteristics of the informal sector as follows: 1) business activities are not well organized, because the business units that arise do not use the facilities or institutions available in the formal sector; 2) generally, the business unit does not have a business license; 3) pattern of irregular business activity both in terms of location and working hours; 4) generally the government's policy to help the weaker economy does not reach this sector; 5) units easily enter from one sub-sector to another sub-sector; 6) the technology used is traditional; 7) capital and business turnover is relatively small, so the scale of operation is also relatively small; 8) in order to run a business there is no need for formal education because the necessary education is gained from experience while working; 9) in general, businesses including groups who work on their own business and workers come from families; 10) the source of business capital funds generally comes from personal savings or from unofficial financial institutions; and 11) production or service is mainly consumed by low-income towns or villages but sometimes also middle-income.

Based on the above description the authors identify characteristics of informal sector in this article as follows. First, this sector has pattern of irregular activities in terms of time, capital, and acceptance. Second, capital, equipment, or turnover is usually small and cultivated on a daily basis. Third, the informal sector has no linkage with other large businesses. Fourth, the business location is either settled or mobile. Fifth, this sector does not require higher education level. Finally, informal sector is an individual business activity or a small business unit that employs a small workforce from a family relation, acquaintance, or from the same neighborhood.

Many factors have contributed to an increase in the number of workers in the informal sector. They include: legal and institutional frameworks for employment with which many workers are unable to comply, economic crises and economic restructuring at both national and global levels, an insufficient number of jobs, increasing poverty (especially among women) and demographic factors, including migration (ILO, 2006). In Indonesia the magnitude of the informal sector makes it an important source of livelihood and, in challenging economic conditions, this sector has important roles to play, particularly as a "survival strategy" for the urban poor.

Increased flows of rural-urban migration contribute to the growth of the urban population. This is a challenge to governments in their efforts to ensure the social and economic well-being of people living in urban areas. The main challenge is to improve household livelihoods and food security, and this will involve the determination of appropriate roles for informal activities. Those in the informal sector are not involved in urban planning and lack of research on informal sector workers, especially street vendors, has resulted in a lack of appreciation their contribution to economic growth and sustainable development.

Based on the above background it appears some research questions, including: What is the general overview of the socio-economic characteristics and the welfare of street vendors? How is the relationship between socio-economic characteristics to the welfare of street 
vendors? Which socio-economic characteristics variable has a significant relationship with the welfare of street vendors? In this paper, income is used as an indicator of welfare. To answer the relationship of socio-economic characteristics on the welfare of street vendors, the following hypothesis is made: There is a relationship between the socio-economic characteristics variable of the street vendor and the income of the street vendor.

This research addresses the roles of street vendors in urban development. It is first necessary to establish who these people are and how they vary. Thus, the paper will examine the socio-economic characteristics and the well-being of street vendors. It will construct a welfare model of street vendors based on their socio-economic characteristics. This is an important research activity because of the large size of the informal sector, including street vendors, and therefore the relevance to improving the welfare of the population as a whole and, particularly, the urban poor.

\section{Literature Review}

According to Indira (2014), street vendors are part of the informal economy and they have increased in number in both developed and developing countries. They are those who sell goods or services in a public space from temporary structures, although in some societies they may be formalized through licensing or regulation. In developing countries, millions of people rely on vendors for their daily needs as they often provide goods and services more economically than those available in the formal sector. It is hard to estimate the exact number of people involved because of the high mobility and seasonal variation that is characteristic of this type of work.

Globally, given the size of the informal economy and the large number of street vendors, this should not be regarded as a temporary phenomenon. They should be regarded as workers with actual and potential incomes. If jobs are to be created and sustainable economic growth is to be achieved, then it is necessary that the informal sector be understood by governments and other stakeholders.

Informal sector workers are of two types: self-employed and casual paid labor. Street vendors are almost all in the first category. They provide goods, including food at low prices, for the urban poor. The middle classes also benefit from the reasonably priced offerings of street vendors. Definitions vary depending upon the rationale used to define the informal sector, as well as other factors such as socio-cultural conditions, the economic characteristics of a region and even political stability, so that definitions taken from one place may not work well in another.

Indira (2014) explained that a surge in the number of street vendors occurred in many Asian countries after the financial crisis in 1998, which triggered a sharp rise in the number of street vendors in Thailand, Singapore and Philippines. Many workers lost their jobs in the formal sector and decided to make a living as street vendors. The share of non-agricultural employment of informal workers was $78 \%$ in Africa, 57\% in Latin America and $45-85 \%$ in Asia. Self-employment was more common than wage employment in the informal sector. Although street vendors are prevalent in all countries in these continents and contribute 
significantly to their economies, governments have rarely put in place laws and regulations that make it a hassle-free undertaking. The author concluded that the main problems faced by street vendors in urban areas in Sri Lanka are livelihood insecurity and lack of access to credit. Street vendors of food make a significant contribution to the economy of this country, although they face the same problem as other vendors, namely, lack of security and lack of institutional support.

The National Alliance of Street Vendors of India (NASVI) studies street vendors in seven cities and showed that lower income groups spend a higher proportion of their income on purchasing from street vendors mainly because their goods are affordable. If there were no street vendors in these cities, the urban poor would be worse off. Therefore, even though street vendors are often seen as a problem for urban governance, they are actually solutions to some problems of the urban poor (Indira, 2014).

Njaya (2014) investigated the operations of vendors of street food in Harare, Zimbabwe, including their socio-economic features, spatial distribution and impacts on the local environment and urban life within the context of sustainable development. The study showed that street vending of food, far from being a hindrance to progress, can contribute to sustainable development. The author stated that there is a need to advance the position of street food vendors by strengthening their capacities and skills through training, provision of information and infrastructure so as to enhance their productivity and competitiveness.

Muzaffar, Huq, and Mallik (2009) highlighted the problems of street food vendors in Dhaka city and identified key factors that affect sales revenue. Four major problems were identified related to business operation, business knowledge, extortion, and products and production. The authors explained that business experience and initial capital are two key factors that affect sales revenue. Formal education, however, did not have a significant impact on business performance. Lack of security and the supply of raw materials are two major problems as perceived by the vendors.

Vargas (2013), using empowerment theory as proposed by Hernando De Soto, examined the extent to which formalization, understood as gaining legal status, can empower informal vendors to increase their capital and economic well-being. In the city of Bogotá, Colombia, 169 interviews were conducted in 2012 with street vendors whose businesses had been formalized. Improvements in the vendors' working conditions and incomes were observed, not because of access to formal credit as stated by the theory of formalization but, instead, due to the ability of the vendors to improve their working conditions and be protected from bad weather.

The empirical studies described in the previous paragraphs suggest that access to formal credit, business capital, business experience, location or condition of place of business are factors that influence the income of street vendors.

There are two conflicting opinions regarding the prospects of the informal sector, namely involutionist and evolutionist (Hosier, 1987). The former, also commonly known as the marginalist notion, suggest that the informal sector has unfavorable prospects because of a 
tendency to be exploited intensively by the formal sector because it is subordinate to capitalist mechanisms. The latter perspective, also called, developmentalist, can be seen in the work of Sethuraman (1977) and ILO (1972). According to this view, the informal sector has similar abilities to those possessed by the formal sector, and can increase revenues and can assist in fighting poverty.

The roles and prospects of the informal sectors in Indonesia are still controversial. In fact, the Indonesian government's policy on the management and structuring of the informal sector's economic activities often lack of transparency. For example, the relocation of street vendors implemented by the local government is less responsive. This happens because the government has not involved the street vendors since the beginning of the process from planning to relocating.

The results of Prasetya and Fauzial (2016) study on the socio-economic impact of the relocation of street vendors in the district Buduran Sidoarjo, Indonesia, found that the government does not relocate street vendors in accordance with the stages of the relocation as stipulated in the Minister of Home Affairs Regulation No. 41 Year 2012 which begins from the stage of data collection by the two surveys and registration of street vendors, determining the location of street vendors, transfer and removal of the location of street vendors, until the rejuvenation of the location of street vendors.

In addition, the policy of empowerment of street vendors programmed by the government is still not optimal. Empowerment program of street vendors conducted by the government in accordance with the Minister of Home Affairs Regulation No. 41 Year 2012 on guidelines and arrangement and empowerment of street vendors, includes several programs: improvement of business capability; facilitation of access to capital; facilitation of trade facilities assistance; institutional strengthening; facilitation of increased production; processing, network development and promotion; and coaching and technical guidance.

In some urban areas, informal sector activities continued to be fostered by local government officials. On the other hand, the empirical reality is that informal sector activity is often prohibited even evicted. It shows there are still variations in perceptions and attitudes among local government and participants may be evicted from their places of operation. Government officials often act against the informal sector which is often powerful to do anything about it.

Contrasts in views regarding the potential, permanence and policies regarding the informal sector, as well as the magnitude of the sector in Indonesia, justify further research. The sector is important in the national economy, especially in situations in which many people face the problem of meeting basic everyday needs and erratic business circumstances. The informal sector has important roles to play in contributing to a "survival strategy" for the urban poor. Accordingly, this paper addresses the socio-economic characteristics and business practices of street vendors in an Indonesian city. In an effort to give a voice to marginalized people whose own perspective on their situations are seldom heard.

Associated with research on street vendors in Indonesia, Timothy and Wall (1997) examined street vendors in Yogyakarta, Indonesia, a center for cultural tourism, using the concepts of 
heterogeneity and differentiation, economic linkages, and government involvement. It was found that the street vendors of Yogyakarta, many of whom served predominantly tourists, were a heterogeneous group and exhibited many of the characteristics commonly ascribed to the informal sector: small scale of operation, individual or family ownership and operation, high labor intensity, and reliance on indigenous resources and skills acquired outside the formal sector. However, in contrast to the attributes described in the literature, most worked at their jobs full-time and few Yogyakarta vendors were outsiders. With respect to economic linkages, authors explained since they sell mainly finished products to tourists, there are few forward economic linkages. Much of their stock is produced locally, reflecting the strong craft traditions of the city and the surrounding area. Yogyakarta differs from many other situations with respect to the extent of government involvement with the informal sector. The importance of the vendors on Malioboro Street is officially acknowledged and most Yogyakarta street vendors are legally recognized, licensed, enumerated, taxed and have their own business organizations.

Furthermore, Cukier and Wall (1994) examined the vendors in Bali, Indonesia, which included aspects of demographic and job characteristics, language skills, sources of income and financing, and job satisfaction and perceived status. The vendors under consideration in this study are individual sales products such as carvings, kites, paintings, clothing, jewelry, and other objects including sunglasses and toys, to tourists on the beach and on the street. A quota sample of 30 interviews was conducted in each of Kuta and Sanur. The research findings show that the majority of the vendors in both Sanur and Kuta were teenagers or young adults, male and single. Formal educational attainments of vendors were varied but somewhat limited, embracing elementary (SD), junior high (SMP), and high schools (SMA) in roughly equal proportions with very few having graduated from the latter. Although formal educational attainment were often modest, most respondents were multilingual. They usually are not Balinese but are migrants from elsewhere in Indonesia. Many vendors view their current employment as a means of acquiring the skills required to gain access to employment in formal sector.

Empirical studies of street vendors in Indonesia in the last decade, showed that most of these studies have reviewed the arrangement and relocation to regulate the place of business of the street vendors associated with the city spatial policy, the socio-economic impact caused by the structuring and relocation policy, and several studies regarding the implementation of the relocation policy. So far there appears to be a void of theories about the informal sector in the current literature, especially regarding street vendors and their role as survival strategies for the urban poor in improving their household economy. Likewise, the empirical study of the informal sector in Bali, especially regarding street vendors there is a vacancy in the current literature that examines this matter. This article is expected to be able to cover the lack of studies on street vendors in Bali today. The results of this study provide scientific contributions regarding the characteristics of informal sector workers who have experienced dynamics and development compared to the previous decade. 


\section{Research Methods}

Substantially because of convenience, the city of Denpasar, the largest city in Bali, was selected as the study site. Bali has 8 regencies and 1 municipality, namely Jembrana, Buleleng, Tabanan, Bangli, Karangasem, Klungkung, Gianyar, Badung, and Denpasar. The selection of study site in Denpasar City is based on several considerations: Denpasar is the capital of Bali Province and the central government, with the highest population density and the largest population compared to other regencies/city in Bali Province. According to data from the Central Bureau of Statistics Bali Province (2015), in 2015 the population of Denpasar City totaled 879,098 people, with a population density of 6879 inhabitants $/ \mathrm{km}^{2}$.

Other than that, the number of informal workers by regency/city shows that Denpasar has the third largest number of informal workers $(156,315)$ after Gianyar regency $(177,884)$ and Badung regency $(173,437)$. Although tourism is extremely important to the economy of Bali, Denpasar itself is not a major tourism destination. Therefore, unlike other research on the informal sector in Bali which has been undertaken in tourism areas (e.g. Cukier-Snow and Wall, 1993; Cukier and Wall 1994) and, in part, serving a tourism clientele, this research examines vendors who are catering primarily to a local market.

This research employs quantitative data obtained from primary sources, i.e., it was gathered directly from the researchers subjects using a questionnaire. The population are street vendors who work in Denpasar city. By definition, no sampling frame is available for such individuals who operate outside of the formal system. Therefore, a purposive sampling system was used: potential respondents were identified by driving around Denpasar and identifying individuals subjectively but based on multiple traits according to characteristics that were previously known and documented in the literature. These respondents possess the following characteristics: the business location is permanent and some are moving; the pattern of activities is not regular, either in terms of time, capital, or revenue; the capital, equipment, and turnover is usually small and pursued on a daily basis; has no linkage with other large businesses; it is an individual business activity or a small business unit that employs a small workforce from the family relations, acquaintances, or neighborhood. Field data collection was conducted from July to September 2016. The 136 respondents in this study worked as street vendors in Denpasar.

A questionnaire was designed to gather information on the following variables: Age, Sex, Marital status, Level of education, Migration status, Type of house lived in, Merchandise sold, Working hours, Age of business, Number of employees excluding family, Number of family employed, Use of bookkeeping, Status of business registration, Physical facilities, Additional sources of income, Employment status, Participation in an empowerment program, and Access to capital. These were employed as independent variables. The dependent variables: Welfare as revealed in $\mathrm{Y}_{1}=$ Income of respondents (IDR). For the purposes of analysis, income is grouped into two categories: income below the Minimum Wages of Denpasar City (UMK) and income above UMK.

Two types of data analysis are used: (1) descriptive analysis to obtain an overview of the socio-economic characteristics and the welfare of street vendors, by determining the 
percentage of variable as univariate; (2) A multivariate analysis using binary logistic regression analysis. Logistic regression, according to Hosmer and Lemeshow (2000), is used when the dependent variable $\mathrm{Y}$ is categorical or dichotomous, and the independent variables are categorical or continuous variables. It has the following specifications:

$$
g(x)=\ln \left[\frac{\pi(x)}{1-\pi(x)}\right]=\beta_{0}+\beta_{1} x_{1}+\beta_{2} x_{2}+\ldots+\beta_{p} x_{p}
$$

Where: $\beta$ = regression parameter; $x=$ the independent variable

Logistic regression analysis was performed to look for models of relationships between the welfare variable ( $\mathrm{Y} 1=$ Income of respondents) and the economic and social variables listed above. All data are compiledand analyzed using SPSS 22.0 and MINITAB 17.

\section{Results and Discussion}

The results will be presented in two sections. First, the survey results will be presented and the results of selected cross-tabulations will be discussed. In this section also, reference will be made to the findings of other researchers who have explored the attributes of the informal sector. Then, using the socio-economic information presented in the first section, a welfare model will be presented and discussed.

\subsection{Socioeconomic Characteristics}

Overviews of the socio-economic characteristics of street vendors (PKL) in Denpasar are presented in Tables 1 and 2. The average age is 39 years and most (63.2\%) are male. The pattern shows that the street vendors is dominated by those who are married. Almost all (87.5\%) are married. These findings are consistent with those of Cukier and Wall (1994) for Bali and Timothy and Wall (1997) for Yogyakarta, both of which found that informal workers are also predominantly male. The latter also discovered that the majority (67\%) of street vendors in Yogyakarta were between 20 and 40 years old. Manning and Effendi (1996) explained that the informal sector is mostly occupied by people of middle age (30-49 years). Thus, these findings are not surprising and are consistent with those of other studies.

Table 1. Descriptive analyses of age, working hours, and income $(\mathrm{N}=136)$

\begin{tabular}{lrrr}
\hline & Age & $\begin{array}{c}\text { Working hours } \\
\text { per day }\end{array}$ & \multicolumn{2}{c}{$\begin{array}{c}\text { Average income per } \\
\text { month (million } \\
\text { rupiah) }\end{array}$} \\
\hline Mean & 39.42 & 7.78 & 2.37 \\
Std. Deviation & 10.52 & 2.95 & 1.36 \\
Minimum & 20 & 2.0 & .50 \\
Maximum & 65 & 17.0 & 6.00 \\
\hline
\end{tabular}

Sources: Primary data

However, a wide range of ages is represented in the sample, varying between 20 and 65 years. 


\section{Macrothink}

International Journal of Human Resource Studies

ISSN 2162-3058 2019, Vol. 9, No. 3

Hidayat (1978) argued that the informal sector is easy to enter and is able to accommodate workers of all ages. This apparent flexibility suggests that it is often an alternative employment option for workers who are unable to enter or maintain a position in the formal sector, and that it is able to accommodate an aging workforce, tacting as a shelter for the productive elderly.

Table 2. Socio-economic characteristics of street vendors $(\mathrm{N}=136)$

\begin{tabular}{|c|c|c|}
\hline Variabel & Category & Percentage \\
\hline \multirow[t]{2}{*}{ 1. Sex } & 1. Male & 63.2 \\
\hline & 2. Female & 36.8 \\
\hline \multirow[t]{4}{*}{ 2. Marital status } & 1. Unmarried & 9.6 \\
\hline & 2. Married & 87.5 \\
\hline & 3. Divorced & 0.7 \\
\hline & 4. Widowed & 2.2 \\
\hline \multirow[t]{5}{*}{ 3. Level of education } & 1. No study & 10.3 \\
\hline & 2. Primary school & 30.1 \\
\hline & 3. Junior high school & 33.1 \\
\hline & 4. Senior High School & 23.5 \\
\hline & 5. College & 2.9 \\
\hline \multirow[t]{2}{*}{ 4. Migration status } & 1. Recent & 70.6 \\
\hline & 2. Lifetime & 29.4 \\
\hline \multirow{3}{*}{$\begin{array}{l}\text { 5. Nature of merchandise } \\
\text { services }\end{array}$} & 1. Mobile & 33.8 \\
\hline & 2. Semi-settled & 25.7 \\
\hline & 3. Settled & 40.5 \\
\hline \multirow[t]{3}{*}{ 6. Type of house } & 1. Owened & 16.2 \\
\hline & 2. Rented & 81.6 \\
\hline & 3. Others & 2.2 \\
\hline \multirow{3}{*}{$\begin{array}{l}\text { 7. Duration of running } \\
\text { business }\end{array}$} & 1. $<1$ year & 16.1 \\
\hline & 2. 1 - 3 years & 18.4 \\
\hline & 3. > 3 years & 65.5 \\
\hline \multirow{4}{*}{$\begin{array}{l}\text { 8. Number of } \\
\text { workers/employees } \\
\text { outside the family }\end{array}$} & 1. None & 89.0 \\
\hline & 2. 1 person & 7.3 \\
\hline & 3. 2 persons & 2.2 \\
\hline & 4. $>2$ persons & 1.5 \\
\hline \multirow{4}{*}{$\begin{array}{l}\text { 9. Number of family } \\
\text { workers }\end{array}$} & 1. None & 55.1 \\
\hline & 2. 1 person & 33.1 \\
\hline & 3.2 persons & 7.4 \\
\hline & 4. $>2$ persons & 4.4 \\
\hline \multirow{2}{*}{$\begin{array}{l}\text { 10. Presence/absence of } \\
\text { bookkeeping }\end{array}$} & 1. Exist & 15.4 \\
\hline & 2. Not Exist & 84.6 \\
\hline
\end{tabular}


Table 2. Socio-economic characteristics of street vendors $(\mathrm{N}=136)$ (continuance)

\begin{tabular}{|c|c|c|}
\hline $\begin{array}{l}\text { 11. Status of business } \\
\text { registration }\end{array}$ & 1. Registered & 7.4 \\
\hline \multirow[t]{3}{*}{ 12. Type of merchandise } & 1. Food & 88.2 \\
\hline & 2. Clothing & 5.1 \\
\hline & 3. Other types & 6.7 \\
\hline \multirow[t]{6}{*}{ 13. Physical facilities } & 1. Basket & 7.4 \\
\hline & 2. Mat & 3.7 \\
\hline & 3. Tables & 16.2 \\
\hline & 4. Cart & 62.5 \\
\hline & 5. Warung Semi Permanent & 8.1 \\
\hline & 6. Stall/Kiosk & 2.2 \\
\hline \multirow{2}{*}{$\begin{array}{l}\text { 14. Alternative sources of } \\
\text { income }\end{array}$} & 1. Yes & 20.6 \\
\hline & 2. No & 79.4 \\
\hline \multirow[t]{6}{*}{ 15. Employment status } & 1. Own-account worker & 88.2 \\
\hline & $\begin{array}{l}\text { 2. Self-employed assisted } \\
\text { by temporary }\end{array}$ & \\
\hline & worker/unpaid worker & 2.2 \\
\hline & 3. Employer assisted by & \\
\hline & permanent worker & 3.7 \\
\hline & 4. Employee & 5.9 \\
\hline \multirow{2}{*}{$\begin{array}{l}\text { 16. Participation in the } \\
\text { empowerment program }\end{array}$} & 1. Yes & 3.7 \\
\hline & 2. No & 96.3 \\
\hline \multirow{2}{*}{$\begin{array}{l}\text { 17. Access to business } \\
\text { capital }\end{array}$} & 1. Yes & 35.3 \\
\hline & 2. No & 64.7 \\
\hline \multirow{2}{*}{ 18. Income category } & 1. below UMK & 56.6 \\
\hline & 2. above UMK & 43.3 \\
\hline
\end{tabular}

Sources: Primary data

Regarding eldery in the labor force, Susilawati, Nilakusmawati, and Rimbawan (2014) investigated the factors that influence it in eight districts in Bali province. It was found that majority work (65.6\%) and that the employment status of the elderly is affected negatively by: age, possession of social security or a pension and family income.

Another trait associated with age is that, according to Hidayat (1978), informal sector workers are generally married with limited formal education. These characteristics are observed in this study, in which a third (33.1\%) only has Junior high school and another third $(30.1 \%)$ has Primary school education. Only a quarter $(23.5 \%)$ have Senior high school and $2.9 \%$ have attended college.

Most (70.6\%) street vendors are recent migrants, while $29.4 \%$ are lifetime migrants who had moved to Denpasar many years ago. Cukier-Snow and Wall (1993) and Cukier and Wall (1994) found that many in the informal sector in Bali are migrants from Java. Most $(81.6 \%)$ 
rented their home while only $16.2 \%$ own it. This is similar to the research of Njaya (2014) in urban Harare, Zimbabwe, where $75 \%$ of street food vendors occupied a rented house. Almost all (about 90\%) of our informants rely on income from selling food as their main source of livelihood. This suggests that work as street vendors has helped to reduce unemployment and has improved the livelihoods of those involved.

Data on the nature of the street vendors' operations are presented in Table 2, including the nature of their services and the type of merchandise, physical facilities, working hours, business longevity, number of employees, use of bookkeeping, registration status and availability of alternative sources of income. Whether vendors were mobile (33.8\%), semi-settled $(25.7 \%)$ or operated consistently from the same location $(40.5 \%)$ made little difference to the services provided.

Table 3. Business duration and presence of alternative sources of income

\begin{tabular}{|c|c|c|c|c|}
\hline \multirow[t]{2}{*}{$\begin{array}{l}\text { Duration of running } \\
\text { business }\end{array}$} & \multicolumn{2}{|c|}{$\begin{array}{l}\text { Presence/absence of alternative } \\
\text { sources of income }\end{array}$} & \multicolumn{2}{|c|}{ Total } \\
\hline & Yes & No & $\mathrm{N}$ & $\%$ \\
\hline$<1$ year & $6(21.4 \%)$ & $16(14.8 \%)$ & 22 & 16.1 \\
\hline 1 - 3 years & $7(25.0 \%)$ & $18(16.7 \%)$ & 25 & 18.4 \\
\hline$>3$ years & $15(53.6 \%)$ & $74(68.5 \%)$ & 89 & 65.5 \\
\hline Total $(\mathrm{N})$ & 28 & 108 & 136 & \\
\hline$\%$ & 20.6 & 79.4 & & 100.00 \\
\hline
\end{tabular}

Sources: Primary data

Duration of running the business can be an indicator of business reliability as well as the number of new entrants into the informal sector. In addition, duration of the business also affects and reflects business skills and revenue. Unfortunately, interviews only with those currently in business necessarily overlook those who have tried and failed. However, it is extremely difficult to identify failures to learn about their experiences. Most $(65.5 \%)$ had been street vendors for more than three years, suggesting a commitment to such work, whereas $16.1 \%$ who had been involved for less than a year (Table 3). Timothy and Wall (1997) found that street vendors in Yogyakarta had been running their business for an average of 10.8 years, and the range spanned from 1 week to 55 years. Long-term involvement resulted from both the lack of other employment options and the perception that iit provides sufficient economic security. Those in Denpasar with at least three years of involvement in street vending were least likely to have a supplementary source of income (Table 3 ). This is in line with the Cukier-Snow and Wall (1993) who found that most of the street vendors work at their jobs full time. Those in this group were also more likely (47.2\%) than others (mobile $30.3 \%$; semi-settled 22.5\%) to have a settled location from which to operate (Table 4). 
Table 4. Longevity of business and the nature of merchandise services

\begin{tabular}{|c|c|c|c|c|c|}
\hline \multirow{2}{*}{$\begin{array}{l}\text { Duration of } \\
\text { business }\end{array}$} & \multicolumn{3}{|c|}{ Nature of merchandise services } & \multicolumn{2}{|c|}{ Total } \\
\hline & Mobile & Semi-settled & Settled & $\mathrm{N}$ & $\%$ \\
\hline$<1$ year & $6(27.3 \%)$ & $3(13.6 \%)$ & $13(59.1 \%)$ & 22 & 16.1 \\
\hline 1 - 3 years & $9(36.0 \%)$ & $10(40.0 \%)$ & $6(24.0 \%)$ & 25 & 18.4 \\
\hline$>3$ years & $27(30.3 \%)$ & $20(22.5 \%)$ & $42(47.2 \%)$ & 89 & 65.5 \\
\hline Total $(\mathrm{N})$ & 46 & 34 & 56 & 136 & \\
\hline$\%$ & 33.8 & 25.7 & 40.5 & & 100.00 \\
\hline
\end{tabular}

Sources: Primary data

The average length of the working day is 7.78 hours ( 8 hours), with a range from 2 hours to 17 hours. Street vendors who work $\leq 8$ hours mostly focus on evening (18.00-24.00) sales work a normal day (10:00 to 17:00), while those working $>8$ hours operate from morning until night (8:00 to 22:00). The latter are mostly long-term business operators with a fixed location.

Most $(88.2 \%)$ vendors sell food/beverages with the rest $(11.8 \%)$ selling clothes and other items. Most (62.5\%) used a cartor stroller. $16.2 \%$ used tables, $8.1 \%$ semi-permanent stalls, $7.4 \%$ used a basket, $3.7 \%$ spread their wares on a mat and $2.2 \%$ had a stall or kiosk. Many use a doorway as a place of business. Mramba (2015) explained that in Tanzania, the mode of operation varies from vendor to vendor, depending on the type of product sold. Products are carried and displayed on tables, carts, bicycles and baskets, and carried by hand, on the shoulder, or by using containers built from boxes and burlap bags.

Table 5. Distribution of respondents according to labor help

\begin{tabular}{lccc}
\hline Labor type & Number of labor & \multicolumn{2}{c}{ Total } \\
\cline { 3 - 4 } & & $\mathrm{N}$ & $\%$ \\
\hline \multirow{2}{*}{ No additional labor } & 0 & 60 & 44.1 \\
\cline { 2 - 4 } & & & \\
& 1 person & 45 & 33.1 \\
Use Family labor & 2 people & 10 & 7.4 \\
& $>2$ people & 6 & 4.4 \\
\cline { 2 - 4 } Casual (non-permanent) & 1 person & 10 & 7.4 \\
labor/salaried & 2 people & 3 & 2.2 \\
& $>2$ people & 2 & 1.5 \\
\hline
\end{tabular}

Sources: Primary data

According to Wirosarjono (1985), few in the informal sector employ other workers, other than family members or, occasionally, acquaintances from the same region. In this study, almost half (44.1\%) use no additional labor, and 44.9 use family members, usually just one, to help run the business. Only, $11.1 \%$ use other labor (Table 5). Similarly, Njaya (2014) explained that, in Zimbabwe, the majority (55 percent) of street food vending is done by 
small businesses of one person or with the help of family members who are not paid. Being informal, only $15.4 \%$ who do the bookkeeping and only a small fraction (7.4\%) have business registration. Few (3.7\%) are attempting to upgrade their skills. Access to capital is a challenge: most (62.5\%) do not have such access and those that do rely on their own resources or draw upon a bank, village credit institutions (Lembaga Perkreditan Desa/LPD), cooperative or family support. Other studies (e.g., Indira, 2014; Mraba, 2015) confirm the problem of lack of access to capital, which is compounded by lack of security, unfavorable urban development policies, abuse by business owners in the formal and a low level of business skills. Nilakusmawati (2009), who studied sellers of offering flowers in Denpasar, confirmed the lack of access to capital. Muzaffar, Huq, and Mallik (2009), in a study of street food vendors in Dhaka, Bangladesh, suggested that the two main factors that positively affect sales revenue are initial capital and business experience. Bhowmik (2005) in his study in Cambodia, explained that access to credit is a major problem for women street vendors, who use their own savings or borrow from moneylenders at high interest rates. He also noted that street food vendors in Guwahati, India, depend primarily on loans from friends, family or moneylenders.

The findings that have been reported for Denpasar are very similar to those that have been undertaken in other parts of the world. Furthermore, there appears to have been little change over the years in the situation in Bali. Thus, the findings of Cukier-Snow and Wall (1993) and Cukier and Wall (1994), even though did their studies in tourism destinations approximately twenty years ago, are very similar to those found in the current investigation.

\subsection{Welfare Model Based on the Socio-economic Characteristics of Street Vendors}

In this paper, income is used as an indicator of welfare and is the dependent variable employed in the regression analyses. The average monthly income of respondents is 2.3699 million IDR, with a large range from 500,000 IDR to 6,000,000 IDR. For the purposes of data analysis, respondents were split into two groups according to whether they are above or below the minimum wage of Denpasar, which is 2.007 million IDR. The socio-economic attributes of respondents, listed in Table 2, are used as independent variables in a binary logistic regression analysis.

Table 6. Simultaneous test results of vendors' income and socio-economic characteristics

Log-Likelihood $=49,213$

Test that all slopes are zero: $\mathrm{G}=40,102, \mathrm{DF}=20, \mathrm{P}$-Value $=0.005$

The hypotheses are as follows:

Hi: There is a relationship between street vendors' socioeconomic variables and income

The results of simultaneous testing and the log-likelihood test using SPSS 22 are shown in Table 6 according to which Ho is rejected at the 5\% level, confirming that relationships exist between vendors' income and their socio-economic characteristics.

These results led to the next step that entails a further partial test to identify independent 
variables that significantly affect the income of street vendors. The test used is the Wald test and the hypotheses is structured as follows:

Ho: $\beta_{\mathrm{j}}=0$

Hi: $\beta_{\mathrm{j}} \neq 0$

Wald test results are presented in Table7.

Table 7 shows that the income of street vendors is influenced significantly by marital status, age, employment status, physical facilities, and bookkeeping for business operations. The regression equation takes the following form:

$\mathrm{G}(\mathrm{x})=-1.348+0.919$ Employment status +1.383 Marital status -0.053 Age -2.212 Bookkeeping +0.65 Physical facilities

Table 7. Results of the partial test of vendors' income and socio-economic characteristics Variables in the Equation

\begin{tabular}{llrrrrrr} 
& \multicolumn{1}{c}{ B } & \multicolumn{1}{c}{ S.E. } & \multicolumn{1}{c}{ Wald } & df & \multicolumn{1}{l}{ Sig. } & \multicolumn{1}{c}{ Exp(B) } \\
\hline Step $1^{\text {a }}$ & Employment status & $\mathbf{. 9 1 9}$ & $\mathbf{. 4 1 2}$ & $\mathbf{4 . 9 8 3}$ & $\mathbf{1}$ & $\mathbf{. 0 2 6}$ & $\mathbf{2 . 5 0 6}$ \\
& Empowerment & .224 & 1.321 & .029 & 1 & .865 & 1.252 \\
Access to Capital & .481 & .527 & .833 & 1 & .361 & 1.617 \\
Physical Facilities & $\mathbf{. 6 5 0}$ & $\mathbf{. 2 7 4}$ & $\mathbf{5 . 6 2 6}$ & $\mathbf{1}$ & $\mathbf{. 0 1 8}$ & $\mathbf{1 . 9 1 6}$ \\
Alternative Income & -.189 & .606 & .097 & 1 & .755 & .828 \\
Type of merchandise & -.094 & .233 & .163 & 1 & .686 & .910 \\
Working hours & -.101 & .080 & 1.608 & 1 & .205 & .904 \\
Duration of business & .515 & .337 & 2.332 & 1 & .127 & 1.673 \\
Number non-family labor & -.088 & .534 & .027 & 1 & .869 & .916 \\
Number family labor & .631 & .343 & 3.383 & 1 & .066 & 1.879 \\
Bookkeeping & $\mathbf{. 2 . 2 1 2}$ & $\mathbf{. 7 8 4}$ & $\mathbf{7 . 9 5 4}$ & $\mathbf{1}$ & $\mathbf{. 0 0 5}$ & $\mathbf{. 1 0 9}$ \\
Business registration & -1.329 & .996 & 1.782 & 1 & .182 & .265 \\
Age & $\mathbf{. 0 5 3}$ & $\mathbf{. 0 2 7}$ & $\mathbf{3 . 9 9 0}$ & $\mathbf{1}$ & $\mathbf{. 0 4 6}$ & $\mathbf{. 9 4 8}$ \\
Sex & & & 1.803 & 3 & .614 & \\
Sex(1) & .104 & .947 & .012 & 1 & .913 & 1.109 \\
Sex(2) & .799 & .697 & 1.311 & 1 & .252 & 2.223 \\
Sex(3) & .628 & .593 & 1.121 & 1 & .290 & 1.873 \\
Marital status & $\mathbf{1 . 3 8 3}$ & $\mathbf{. 6 7 5}$ & $\mathbf{4 . 2 0 0}$ & $\mathbf{1}$ & $\mathbf{. 0 4 0}$ & $\mathbf{3 . 9 8 7}$ \\
Level education & .125 & .261 & .229 & 1 & .632 & 1.133 \\
Migration status & .173 & .615 & .079 & 1 & .778 & 1.189 \\
Type of house & .222 & .710 & .098 & 1 & .755 & 1.248 \\
Merchandise services & .03 & .181 & .028 & 1 & .867 & 1.031 \\
Constant & -1.348 & 4.963 & .074 & 1 & .786 & .260 \\
\hline
\end{tabular}

a. Variable(s) entered in step 1: Employment status, Empowerment, Access Capital, Physical Facilities, Alternative Income, Type of merchandise, Working hours, Duration business, 
Number non-family labor, Number family labor, Bookkeeping, Business registration, Age, Sex, Marital status, Level of education, Migration status, Type of house, Merchandise services

Interpretation of the above models is based on the odds ratio (OR) value of each variable in the model. The value of the OR is obtained from the exponential regression coefficient $\left(\mathrm{e}^{\mathrm{b}}\right)$. In the variable marital status $\mathrm{OR}=3.987$ indicating that married workers have 3.987 times the chance of unmarried workers of earning above the minimum wage for Denpasar. This may be because of the availability of additional family members to help with the business, increasing business capacity and revenue.

The OR value for age is 0.948 , indicating that an increase in age of one year reduces income, i.e. young workers tend to make more than older ones. For bookkeeping, the OR value of 0.109 indicates absence of bookkeeping reduces the chance by 0.109 times compared to those using bookkeeping of having an income above the minimum wage for Denpasar. Use of physical facilities support business, the OR of 1.916 indicates almost twice the prob physical facilities used by vendors had OR of 1.916. This indicates that ability of having a minimum wage above that for Denpasar.

The 2.506 OR value for employment status indicate that vendors who are assisted by a permanent worker are more likely to have an income above the minimum wage for Denpasar in comparison with those working alone or with temporary assistance.

\section{Conclusion and Recommendations}

Street vendors in Denpasar are mainly male, married, with an average age of 39. Most are recent migrants who live in rented accommodation. Most have been in business for more than 3 years and operate from a consistent location, often a doorway, a food seller with operating time from evening to night. They work an average of 7.78 hours per day with a large variation among operators. Almost half $(44.1 \%)$ are sole operators but many are assisted by family members and relatively few use paid casual labor. Few use bookkeeping, are registered or have a license or are attempting to upgrade their skills. Access to capital is one of their most widespread challenges.

Comparison of the above findings with those reported for other locations suggests that these results are not unusual for similar findings have been reported for the informal sector, especially street vendors, in other parts of the world. Also, comparison with earlier studies undertaken in Bali suggests that the situation has changed little over a twenty-year period.

The relationship between socio-economic characteristics to the income of street vendors based on the model obtained, it was found that variables that influence the income of street vendors are marital status, age, employment status, physical facilities, and presence/absence of bookkeeping. Marital status explains that married workers have greater chances than unmarried ones to earn income above the minimum wage for Denpasar. The model also shows that the increase in the age of street vendors will decrease their income. Older street vendors tend to have lower incomes than younger street vendors. The street vendors with status of self-employed assisted by permanent workers are more likely to have income above 
the minimum wage for Denpasar compared with street vendors with self-employed assisted by temporary worker/unpaid worker. As for the physical facilities used by street vendors, indicating that the more support the facilities used, the greater the chances of having income above the minimum wage for Denpasar. The absence of bookkeeping is less likely to be compared to street vendors who have bookkeeping for business operations to earn income above the minimum wage for Denpasar.

Logistic regression analysis indicates that younger, married operators who have access to additional labor and use physical facilities, such as a cart, bookkeeping are more likely to have an income that is above the minimum level for Denpasar. However, the direction of influence is not clear i.e. whether relative success is more likely for those with such attributes or whether success facilitates the use of physical facilities and bookkeeping.

The government has introduced an empowerment program to encourage those in the informal sector to upgrade their skills and/or to gain access to business capital. Street vendors empowerment program conducted by the government in accordance with the Regulation of Home Affairs Number 41 Year 2012 includes several programs: improvement of business capability; facilitation of access to capital; facilitation of trade facilities assistance; institutional strengthening; facilitation of increased production; processing, network development and promotion; and coaching and technical guidance. Very few of our informants are involved in the empowerment program. This program should be evaluated to see if it can be modified to better meet the needs of potential clients, thereby enhancing the productivity and competitiveness of vendors. More effective initiatives are required to strengthen the capacity and skills of vendors through training, access to credit, and improvement of infrastructure and information flows. Particularly with respect to food vendors, to ensure the safety of food sold in the streets, it may be necessary to license vendors and provide training on food hygiene, thereby improving the quality of food sold on the streets.

\section{References}

Bhowmik, S. K. (2005). Street vendors in Asia: a review. Economic and Political Weekly, May 28-June 4, 2256-2264. Available: http://www.wiego.org/sites/default/files/publications/files/Bhowmik-Street-Vendors-Asia.pdf

BPS Provinsi Bali. (2012). Keadaan ketenagakerjaan Provinsi Bali Agustus 2012. [online] Available:

https://bali.bps.go.id/publication/2012/10/10/a490d5e1774cbc3878d5f39e/keadaan-ketenagak erjaan-di-provinsi-bali-agustus-2012.html (March 8, 2016).

BPS Provinsi Bali. (2015). Peta tematik hasil SUPAS 2015 Provinsi Bali. Denpasar: Badan Pusat Statistik Provinsi Bali.

BPS. (1996). Survei angkatan kerja nasional. Jakarta: Biro Pusat Statistik.

BPS. (2002). Statistik Indonesia 2002. Jakarta: Biro Pusat Statistik.

Carol, N., \& Ongori, H. (2013). An assessment of challenges faced by microenterprises in Botswana: a case of street food vendors in Gaborone. International Journal of Learning \& 
Development, 3(5), 56-73. https://doi.org/10.5296/ijld.v3i5.4470

Cukier, J., \& Wall, G. (1994). Informal tourism employment: vendors in Bali, Indonesia. Tourism Management, 15(6), 464-467. https://doi.org/10.1016/0261-5177(94)90067-1

Cukier-Snow, J., \& Wall, G. (1993). Tourism employment: perspectives from Bali. Tourism Management, 14(3), 195-201. https://doi.org/10.1016/0261-5177(93)90020-L

Effendi, T. N. (1993). Sumber daya manusia, peluang kerja dan kemiskinan. Yogyakarta: Tiara Wacana.

Friedmann, J., \& Sullivan, F. (1974). The absorption of labour in the urban economy: the case of developing countries. Economic Development and Cultural Change, 22(3), 385-413. https://doi.org/10.1086/450727

Hidayat. (1978). The urban informal sector of Indonesia: an empirical search for solution. Jakarta: YKTI.

Hosier, R. H. (1987). The informal sector in Kenya: spatial variation and development alternatives. Journal of Developing Areas, 24, 383-402.

Hosmer, D. W., \& Lemeshow, S. (2000). Applied Logistic Regression. New York: John Wiley and Sons, Inc. https://doi.org/10.1002/0471722146

ILO (1985) Informal sector in Africa. Addis Ababa: Jobs and Skill Programme for Africa. Geneva: International Labor Office.

ILO. (1972). Employment, income, and equality: a strategy for increasing productive employment in Kenya. Geneva: International Labor Office.

ILO. (2002). Decent work and the informal economy. Geneva: International Labor Office.

ILO. (2006). Indonesia: decent work country programme 2006-2010. [online] Available: https://www.ilo.org/wcmsp5/groups/public/@asia/@ro-bangkok/@ilo-jakarta/documents/poli cy/wcms_115007.pdf (March 8, 2016).

Indira, D. (2014). A study of street vending across the globe. International Journal of Advanced Research in Computer Science and Software Engineering, 4(9), 514-519. Available: http://www.ijarcsse.com/docs/papers/Volume_4/9_September2014/V4I9-0256.pdf (March 8, 2016)

Kasmad, R., \& Alwi. (2014). Analysis of local government capacity building network in empowering street vendors policy implementation in Makassar City, Indonesia. European Journal of Research in Social Sciences, 2(2), 29-40. Available: http://www.idpublications.org/wp-content/uploads/2014/04/ANALYSIS-OF-LOCAL-GOVE RNMENT-CAPACITY-BUILDING-NETWORK-IN-EMPOWERING-STREET-VENDORSPOLICY.pdf (March 12, 2016)

Kasmad, R., \& Alwi. (2015). Democratic model of public policy accountability. Case study on implementation of street vendors empowerment policy in Makassar city. Journal of Government and Politics, 6(2), 186-202. https://doi.org/10.18196/jgp.2015.0014

Leibo, J. (2004). Problem perkotaan dan konflik sosial. Yogyakarta: Institut Pengembangan Demokrasi dan Hak Asasi Manusia.

Long, V., \& Wall, G. (1995). Small-scale tourism development in Bali. In: Conlin, M. V., \& 
Baum, T. (Eds.), Island Tourism: Management Principles and Practice (pp. 237-257). Chichester: Wiley.

Manning, C., \& Effendi, T. N. (1996). Urbanisasi, pengangguran, dan sektor informal di kota. Jakarta: Yayasan Obor Indonesia.

Minister of Home Affairs Regulation No. 41 Year 2012 on Guidelines and Arrangement and Empowerment of Street Traders. Available: http://ditjenpp.kemenkumham.go.id/arsip/bn/2012/bn607-2012.pdf (April 25, 2018)

Mramba, N. R. (2015). The conception of street vending business (SVB) in income poverty reduction in Tanzania. International Business Research, 8(5), 120-129. https://doi.org/10.5539/ibr.v8n5p120

Muzaffar, A. T., Huq, I., \& Mallik, B. A. (2009). Entrepreneurs of the streets: an analytical work on the street food vendors of Dhaka city. International Journal of Business and Management, 4(2), 80-88. https://doi.org/10.5539/ijbm.v4n2p80

Neter, J., Wasserman, W., \& Kutner, M. H. (1997). Model linear terapan Buku II. Analisis regresi ganda. Translated by Bambang Sumantri. Bandung: Jurusan Statistika FMIPA IPB.

Nilakusmawati, D. P. E. (2009). Kajian aktivitas ekonomi pelaku sektor informal di kota Denpasar (Studi kasus wanita pedagang canang sari). Piramida, 5(2), 54-64. Available: https://ojs.unud.ac.id/index.php/piramida/article/view/2993 (April 25, 2018)

Njaya, T. (2014). Operations of street food vendors and their impact on sustainable urban life in high density suburbs of Harare, in Zimbabwe. Asian Journal of Economic Modelling, 2(1), 18-31. Available: http://www.aessweb.com/pdf-files/Ajem-2014-2\%281\%29-18-31.pdf (March 17, 2016)

Prasetya, M. A., \& Fauzial, L. (2016). Dampak sosial ekonomi relokasi pedagang kaki lima di Kecamatan Buduran Kabupaten Sidoarjo. Jurnal Kebijakan dan Manajemen Publik, 4(2), 117-234. https://doi.org/10.21070/jkmp.v4i2.691

Sethuraman, S. V. (1977). The Urban Informal Sector in Africa. International Labour Review, 116(3), 343-352.

Sjahrir, K. (1985). Sektor informal: beberapa catatan kritis. Prisma, XIV(6), 74-83.

Soewartoyo. (2010). Pekerja sektor informal: pemberdayaan dan peningkatan kesejahteraan. (Laporan Program Insentif Peneliti dan Perekayasa LIPI). Jakarta: Pusat Penelitian Kependudukan, Lembaga Ilmu Pengetahuan Indonesia.

Subarsono. (1998). Kebijakan sektor informal. Jurnal Kebijakan dan Administrasi Publik (JKAP), 2(1), 81-95.

Susilawati, M., Nilakusmawati, D. P. E., \& Rimbawan, D. (2014). Determinan dari status pekerjaan berdasarkan karakteristik sosial ekonomi lanjut usia di perdesaan Provinsi Bali. In: Prosiding Seminar Nasional Sains \& Teknologi 2014, Denpasar, Indonesia, 18-19 September 2014, pp. 895-902. Denpasar: LPPM Universitas Udayana Bali.

Timothy, D. J., \& Wall, G. (1997). Selling to tourists Indonesian street vendors. Annals of Tourism Research, 24(2), 322-340. https://doi.org/10.1016/S0160-7383(97)80004-7

Vargas, A. M. (2013). Legal empowerment of informal workers: alternative models of regulation for street vendors in Bogota, Colombia. In: Conference Regulating For Decent 
Work, 2013. 2019, Vol. 9, No. 3 http://lup.lub.lu.se/luur/download?func=downloadFile\&recordOId=3954825\&fileOId=39548 28 (March 8, 2016)

Wirosardjono, S. (1985). Pengertian, batasan, dan masalah sektor informal. Prisma, 15(3), 3-10.

\section{Copyright Disclaimer}

Copyright for this article is retained by the author(s), with first publication rights granted to the journal.

This is an open-access article distributed under the terms and conditions of the Creative Commons Attribution license (http://creativecommons.org/licenses/by/4.0/). 